\title{
Cultural Reconstruction and Organization Environment for Employee Performance
}

\author{
Tehubijuluw Zacharias ${ }^{1}$ \\ Universitas Kristen Indonesia, Maluku, Indonesia \\ Mohamad Arsad Rahawarin \\ Universitas Pattimura, Maluku, Indonesia \\ Yusriadi Yusriadi \\ Sekolah Tinggi Ilmu Administrasi Puangrimaggalatung, Makassar, Indonesia
}

\begin{abstract}
This study examined cultural and organizational motivations for success through organizational engagement and work motivation in the Department of Public Works in the province of Maluku, Indonesia. The approach used for this study was quantitative, using a survey. The Department of Public Works of the Province of Maluku was the research site with a sample of 149 participants. The analysis method used in this study was Generalized Structured Component Analysis (GSCA). The main findings were 1) organizational culture has a direct effect on organizational engagement and a direct contribution to employee performance, 2) organizational culture impacts company performance, 3) organizational environment has a direct effect on employee motivation and employee performance, and 4) organizational environment supports company performance. The results indicate that the organizational environment can be increased by formulating regulatory policies and establishing rules and strategies for employees to carry out their duties. Motivation for work can be boosted by giving awards that match the results of work. In building an organizational culture, attention needs to be paid to the values contained in organizational culture, consisting of corporate empowerment, team management, clarity of vision, direction, and corporate goals.
\end{abstract}

Keywords: cultural, engagement, environment, employee, Indonesia motivation, performance.

The effective and efficient use of human resources is beneficial for supporting sustainable national development. Thus, existing human resources must be used optimally (Tarman, 2018). Providing the community with reliable human resources requires quality education, offering various social facilities, adequate employment (Yusriadi et al., 2019), but weaknesses in delivering these facilities will cause social unrest, affecting public safety.

One challenge facing the Indonesian people today is the low quality of human resources (Umar et al., 2019). Currently, human resources are still low in terms of intellectual skills and technical skills. One element that affects employees' interactions is the corporate culture that surrounds it. As social beings, employees are inseparable from the values and norms that exist within a company. Culture can affect how employees behave, how they think about their work,

${ }^{1}$ Corresponding Author E-Mail: tehubijuluwzacharias@yahoo.com 
how they work with their colleagues, and how they look to the future with broad insights that their norms, values, and beliefs determine (Karakuş, 2018).

Substantial human resources will help a company achieve its goals; on the other hand, weak human resources can impede or interfere with achieving an organization's goals (Závadská \& Závadský, 2020). Organizational culture includes standards for deciding what to do and how to do it. As a result, a corporate culture is a management tool that affects and acts as an incentive for employees to work positively and productively (Tamsah et al., 2020). Cultural principles become evident and become a guiding force in human resources to produce employee success. A healthy and optimistic culture has a significant impact on employee actions and the effectiveness of company success.

Changes in technology with online service-based necessitate that all elements keep up with the changes that continue to occur at the Maluku Province Public Works Office, which is necessary to provide good services to the community. The changes that arise are problems that require the government's serious attention to strengthen organizational management (Mustafa et al., 2020). Currently, globalization has entered a new era called the Industrial Revolution 4.0, which is a change in the way humans think, live, and relate to one another, a significant difference in the field of technology (Závadská \& Závadský, 2020). In the age of the Fourth Industrial Revolution, information technology requires all government components as institutions constantly prepare themselves, especially the quality of human capital, in facing the challenges of new globalization, in public services. The information technology in question is applied in the form of electronic government or e-Gov. The e-Government superstructure includes, among others, institutional management leadership (e-leadership), human resources (human resources), and regulations at the institutional level related to the development of e-Government (principle) (Manoharan et al., 2021).

Service changes are not something new in the current era of globalization, and the government has invented several to provide convenience in terms of services. Many new ideas were created to face the transition, including the Department of Public Works in the Maluku province. Each local government aims to provide better service by introducing new ideas (Jung et al., 2009). New ideas can be seen in everything from enhancing service quality to offering services for the community's convenience.

The formulation of technical policies on government affairs in the public works sector and the housing and residential areas are needed. As a result, the Public Works Office plays an essential role in meeting the growing demand for residential space. The Public Works Office in Maluku Province is one of the departments that offers housing and residential area services. In this area, service is described as a process of assisting the community. The interconnection of these service processes must complement the settlement area processes to operate smoothly and comply with the government's procedures. Human resources and organizational culture are significant challenges for management because their effectiveness depends on human resource quality.

Ostroff et al. (2012), organizational culture often plays an active role in deciding its strategies, structures, procedures, and objectives. Achieving objectives is possible without employees' active participation, and the funding of facilities and sources of funds held by an organization would be of no benefit to the company if it did not include the active participation of employees. This argument illustrates that human resources are the primary keys of corporate culture and must be considered for all their needs. As a result, the government must pay attention to the human element to function more efficiently and meet the organization's goals. 


\section{Literature Review}

\section{Human Resources}

Professional human resource management in companies is now embodied in administration as an open framework, including human resource management activities integrated and highly affected by environmental changes (Chatman \& O'Reilly, 2016). As a result, human resources in public services must constantly cope with shifts in organizational culture. Continuously updating information is necessary because the evolution of the human resource paradigm shifts rapidly, necessitating proactive and adaptive knowledge to respond to changes (Becker \& Huselid, 2006). Building the capacity to navigate the change process is often essential because organizational climate changes highly affect the role of human resources in executing their duties in an open system.

Human resources (HR) must contribute to and participate in a strategy's implementation (Tracey, 2014). An organization cannot use HR efficiently if its operations do not contribute to achieving its strategic objectives. As a result, the HR role inside an organization must be involved in executing the company strategy. Any company is responsible for human resources. The improvement and maintenance of HR quality is the responsibility of all internal departments and local governments (Svetlik \& Stavrou-Costea, 2007). The orientation of current HR thinking, such as work requirement problems, job requirements, HR preparation, hiring processes, placement, employee assessment, and compensation structures, cannot be ignored in this approach.

The HR approach is based on the premise that workers' needs would improve job motivation and satisfaction. In other words, an approach must match organizational needs with employee needs. Individual performance is expected to strengthen as job motivation improves, resulting in increased organizational efficiency (Vardarlier, 2016). Through HR growth, a company-oriented HR approach achieves success. HR is the secret to productivity because it prioritizes employee happiness. By predicting threats and opportunities, HR will make more significant contributions to an organization's interests. The new period of globalization presents a challenge in increased competition, forcing the government to restructure for organizational productivity and effectiveness (Lam et al., 2021).

\section{Organizational Culture}

Organizational culture comprises common perceptions that all company participants share. Corporate culture is a system of shared meanings that participants share, distinguishing one organization from another (Buch \& Wetzel, 2001). Organizational culture is a pattern of actions that an organization forms that have been proven to be good and are taught to new members regarding how they understand, think, and feel (Martinez et al., 2015). Any of these characteristics occur on a scale from low to high.

A strong organizational culture will have a more significant effect on employees than a weak culture. Culture should have a powerful and positive influence on employee behavior (Prajogo \& McDermott, 2011). Corporate culture starts from current habits, traditions, and general ways of doing work that has been carried out before and the success of the efforts that have been made. Organizational culture comprises public perception that executive members believe in (Baumgartner, 2009). The more that leaders accept an organization's positive values with the ranks about these values, and feel very attached to them, the stronger a culture will be. 
Organizational culture clearly distinguishes one company from another. Culture gives corporate members a sense of belonging, making it easier to contribute to something larger than personal interests (Linnenluecke \& Griffiths, 2010). This culture contributes to a social system's stability. Culture is the social glue that helps groups collaborate by defining what community members can say and do. Organizational culture serves as a meaning-making and regulating tool, guiding, and shaping executive members' attitudes and actions (Naranjo-Valencia et al., 2011).

The more members of a company who understand the core values, the greater an organization's culture. The fewer members of the organization who recognize and enforce the organization's rules and regulations, the weaker the organizational culture (Bunch, 2007). Employee loyalty to an organization is lower when there is a lack of corporate culture. A comparison is often made between solid and weak cultures for organizations. A strong culture's specific outcome is that its members have a high consensus on its objectives (Alavi et al., 2005). Attachment, loyalty, and organizational dedication can result from unanimity against goals (Miller, 2018). This condition reduces the likelihood of workers leaving and having a sense of belonging in the organization. Based on this, the questions in his research are as follows:

1) Does organizational culture affect organizational engagement?

2) Does organizational culture affect employee performance?

3) Does organizational engagement affect performance?

Thus, the following hypotheses are posited:

- H1: Organization culture affects organizational engagement

- H2: Organizational culture affects performance

- H3: Organizational engagement affects performance

\section{Organizational Environment}

An excellent organizational atmosphere is a state or a good workplace that includes both physical and non-physical elements that can offer the impression of being friendly, safe, serene, and so on (Aktaş et al., 2011). Organizational climate consists of all material conditions in and around the workplace that can impact workers directly or indirectly. A non-physical corporate setting is a friendship with coworkers, supervisors, and others (Boyd, 1990). Any business should be concerned about maintaining a healthy organizational atmosphere (secure, comfortable, and clean). In such a work environment, workers can avoid unnecessary distractions that can hurt morale and impede efficiency (Lockrey, 2015). Environmental cleanliness should be a joint duty, with all workers required to keep their environments clean. A company can gain many advantages if its working atmosphere is well managed (Singh et al., 2011), not only for the business but also for that outside of it.

An organizational climate affects all circumstances around employees, so that it can affect employees in carrying out their assigned duties directly or indirectly (Luo, 2005). A healthy and friendly work environment will generate excitement and enthusiasm for work, while an imperfect and unpleasant work environment will decrease confidence and enthusiasm for work (Eby \& Rothrauff-Laschober, 2012). Every employee desires a friendly organizational atmosphere, as well as a comfortable work climate. Workplace protection is improved using silence and quiet sound (Boiral \& Paillé, 2012). Based on this, the questions in his research are as follows: 
1) Does the organizational environment affect motivation?

2) Does the organizational environment affect performance?

3) Does motivation affect performance?

Thus, the following hypotheses are posited:

- H4: Organizational environment affects motivation

- H5: Organizational environment affects performance

- H6: Motivation affects performance

\section{Conceptual Framework}

Organizational culture and organizational environment are assumed to influence employee performance; thus, if corporate culture and the organizational environment are linked to employee performance, they will have a higher impact (Budiharso \& Tarman, 2020). The influence between organizational culture and organizational environment on employee performance is described as follows:

The influence of organizational culture on performance and every corporate culture is effective if the organization is well disciplined. Discipline can be successful if the culture of the organization applies all procedures consequently. Organizations must avoid favoritism that can give rise to prejudice, resentment, and social jealousy. The framework of thinking about the influence of organizational culture on performance is also supported by research (Goula et al., 2021). The findings of the research show that corporate culture can positively and significantly affect employee performance. For example, Wang and Lounsbury (2021) found a positive and significant impact on employee performance.

Mahrous et al. (2020) explained that an organizational environment is an environment for respecting, obeying, and obeying administrative rules, carrying out and receiving sanctions if it violates duties and authorities. Kuenzi et al. (2020) argued that the organizational environment is an orderly state of the organization in which employees are happy to obey the rules. This framework of thinking about the influence of the corporate environment on employee performance is also supported by Paais and Pattiruhu (2020). The study's findings show that the organizational climate has a positive and significant effect on employee performance.

The conceptual framework in Figure 1 illustrates the direct and indirect relationship between variables.

\section{Figure 1}

Conceptual Framework

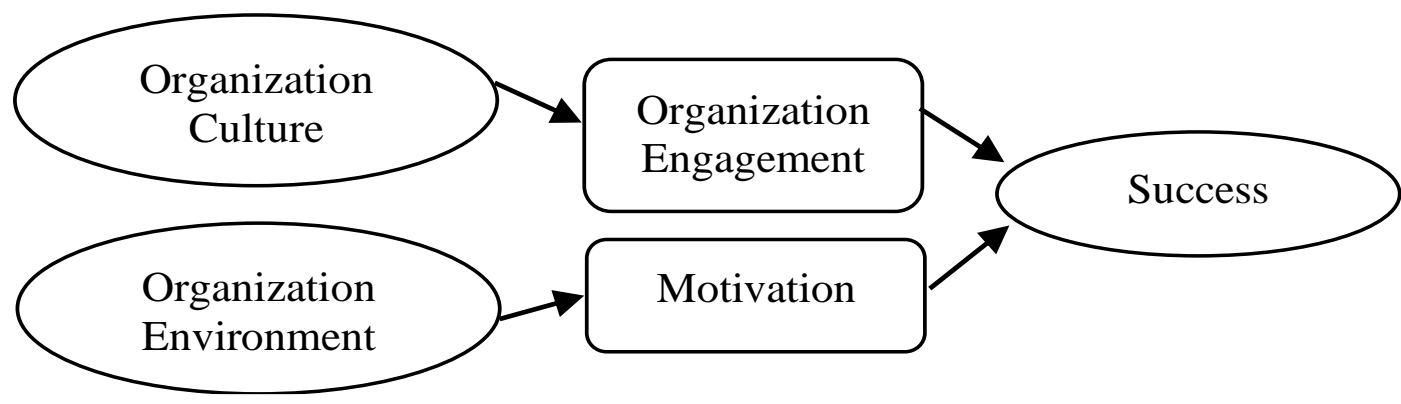




\section{Methodology}

\section{Research Design and Approach}

This study used a survey to provide information to answer the main problems posed. The survey had 5 sections. The sections included 6 statements concerning organizational culture, 5 statements concerning organizational culture, 5 statements organizational engagement, 5 statements concerning motivation, and 5 concerning success. Potential responses used a Liker-type scale of $1-10$, with responses ranging from $1=$ totally disagree to $10=$ strongly agree. See Table 1 for the statements used.

\section{Table 1}

Statements Used

\begin{tabular}{l} 
Scale \\
\hline Organizational Culture \\
Organizational culture is a pattern of behavior developed \\
by an organization's employees learned when faced with \\
problems of external adaptation and internal integration.
\end{tabular}

\section{Organizational Environment}

Good management thinks of a good and pleasant organizational environment because its workforce needs it.

\section{Source(s)}

(Schein, 1990)

\section{Organizational Engagement}

The level of employee involvement in the organization (Albrecht et al., 2018) and have the same identity as the organization.

\section{Motivation}

Something that encourages someone to work. The (Lindner, 1998) strength and weakness of a person's work motivation will also determine the size of the employee's performance.

\section{Success}

Work results that can be achieved by a person or group people in the organization.

(Machado \& Carvalho, 2008)

Six statements about organizational culture: 1) The organization provides opportunities for employees to develop themselves; 2) The organization provides the opportunity to make decisions according to Main Duties and Functions. 3) The organization provides opportunities for achievement; 4) The organization prioritizes teamwork orientation. 5) The Organization Has a Strong Vision; 6) Employees understand the direction of the organization.

Five statements about the organizational environment: 1) The formal organizational policy is communicated; 2) Organization provides a comfortable workspace. 3) The workload is adjusted to the abilities and competencies; 4) Suitability of wages and workloads. 5) The organization provides rewards for work performance.

Five statements regarding organizational involvement: 1) Employees are willing to accept challenges in carrying out work; 2) Employees are willing to be supervised. 3) Employees provide 
periodic reports to the leadership in stages; 4) Employees are interested in the organization. 5) Employees have positive feelings towards the organization.

Five statements about motivation: 1) Employees are motivated to get high performance in carrying out their work; 2) Employees are motivated to provide good services to the community. 3) Employees are encouraged to build communication with colleagues; 4) Employees are motivated by efforts to meet physical needs. 5) Employees feel safe working as civil servants.

Five statements about success: 1) Work on target; 2) Work following Standard Operating Procedures. 3) Work results are accepted and acknowledged by colleagues and leaders; 4) Work on time. 5) Having good relationships with colleagues and leaders.

\section{Participants and Sampling} Province.

The population comprised all 149 employees of the Public Works Office in Maluku

\section{Data Collection Technique}

For an adequate response in a population of 149, the necessary number of respondents is 105 people, for a confidence level of $95 \%$, according to the sample size table of Isaac and Michael (1995) namely determining the error tolerance limit, this error tolerance limit is expressed as a percentage. The smaller the fault tolerance, the more accurate the sample describes the population. A total of 105 surveys were distributed via email, and the data collection period lasted from April 2020 to June 2020. In total, 102 useable responses were received for a response rate of 97,14\%.

\section{Data Analysis}

This study used the Generalized Structured Component Analysis (GSCA). Generalized Structured Analysis (GSCA) is a modern component-based Structural Equation Modeling (SEM) approach that is important for the estimation of scores (not scales) and small samples. GSCA can also be used in structural models using variables with reflexive and or formative indicators.

In this study the structural model specifications were as follows:

$\mathrm{Y} 1=\mathrm{f}(\mathrm{X} 1)$

$\mathrm{Y} 2=\mathrm{f}(\mathrm{X} 2)$

$\mathrm{Y} 3=\mathrm{f}(\mathrm{Y} 1, \mathrm{Y} 2, \mathrm{X} 1, \mathrm{X} 2)$ follows:

Equations (Y1), (Y2) and (Y3) can be analyzed and made into a regression equation as

$$
\begin{aligned}
& \mathrm{y} 1=\alpha 0+\alpha 1 \mathrm{X} 1+\mu 1 \\
& \mathrm{y} 2=\alpha 0+\alpha 2 \mathrm{X} 2+\mu 2 \\
& \mathrm{y} 3=\beta 0+\beta 1 \mathrm{Y} 1+\beta 2 \mathrm{Y} 2+\beta 3 \mathrm{X} 1+\beta 3 \mathrm{X} 2+\mu 3
\end{aligned}
$$

Equations (y2) and (y3) are two simultaneous equations so that it can obtain the reduced form assumption by rewriting equation (Y3) by substituting equation (y2) to equation (y3) then the reduced form is obtained as follows: 
$\mathrm{Y} 3=\Omega 0+\Omega 1 \mathrm{X} 1+\Omega 2 \mathrm{X} 2+\mathrm{V}$

Where:

$\Omega 0=\beta 0+\beta 0 \alpha 0$ is a constant

$\Omega 1=\beta 1 \alpha 1+\beta 2$ is the direct effect of X1 to Y3 ( $\beta 2)$ and the indirect effect of X1 to Y3 through $\mathrm{Y} 1(\beta 1 \alpha 1)$

$\Omega 2=\beta 1 \alpha 2+\beta 2$ is the direct effect of $\mathrm{X} 2$ to $\mathrm{Y} 3(\beta 2)$ and the indirect effect of $\mathrm{X} 2$ to $\mathrm{Y} 3$ through $\mathrm{Y} 2(\beta 1 \alpha 2)$

$\mathrm{V}=$ random error $\mu 1$ and $\mu 2$

Equation (Y3) explains that the exogenous variables are organizational culture (X1) and organizational environment (X2), and the endogenous variables are organizational engagement (Y1), motivation (Y2), and performance (Y3).

\section{Figure 2}

Path Diagram of the Theoretical Model

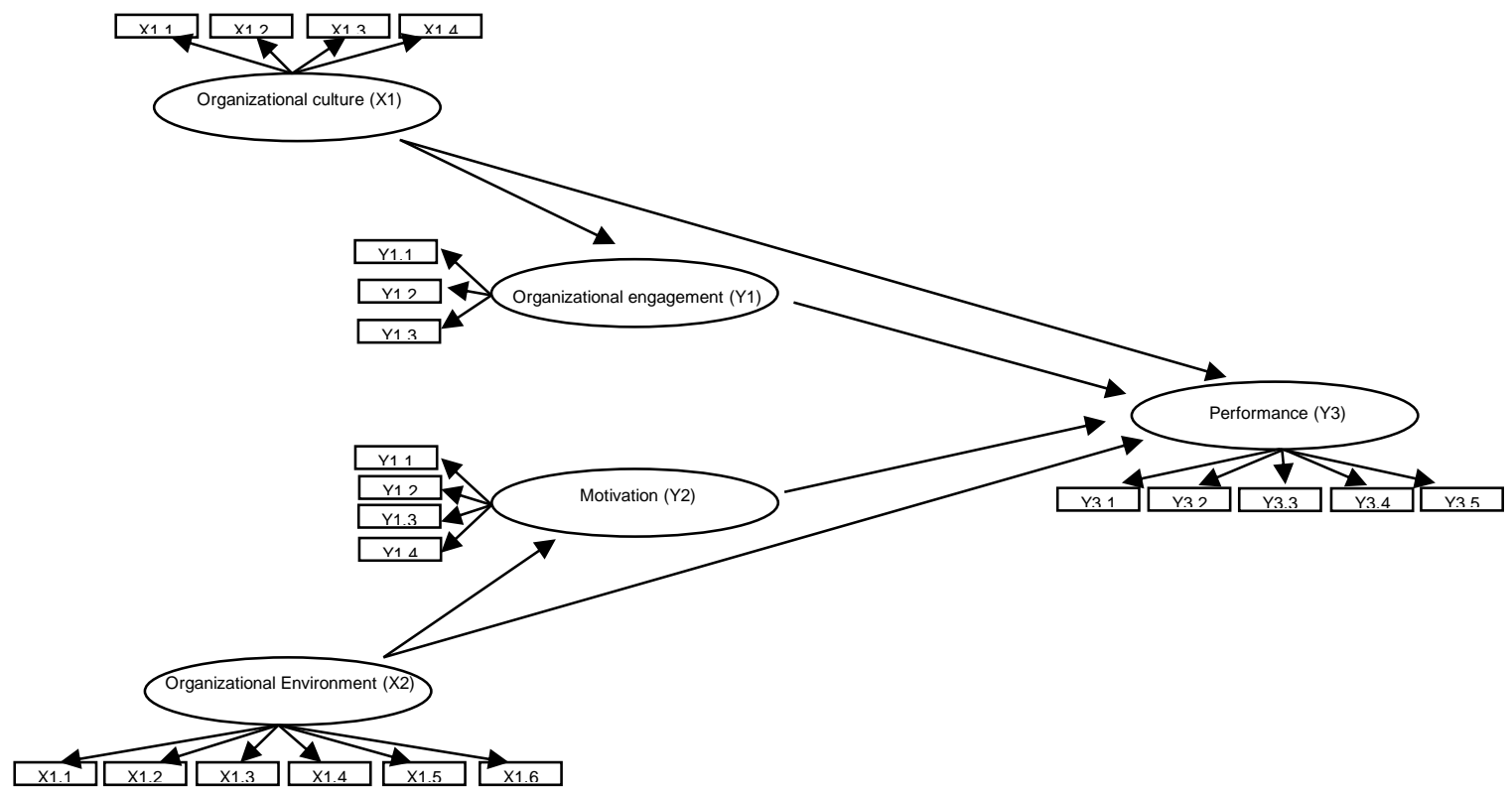

\section{Results}

Structural Equation Model (SEM) is a multivariate statistical technique using a combination of factor analysis with regression analysis (correlation), aiming to examine the relationship between variables in a model, including indicators with constructs or relationships between constructs. The predictor is the variable measured (the index is used as the operation of the calculation of the latent variable). After the designs and indicators set out in the plan, validation and reliability tests are carried out. Model-checking was used to determine the level of suitability.

Table 2 indicates the seven parameters used to determine the viability of a model that satisfies all the specifications that have been met, so there is no need for adjustment. The model was acceptable, which means a match between the model and the data. 
http://dx.doi.org/10.29333/ejecs/801

\section{Table 2}

Conformance Index Model

\begin{tabular}{cccc}
\hline Criteria & Cut-off value & $\begin{array}{c}\text { The calculation } \\
\text { results }\end{array}$ & Information \\
\hline Chi-Square & $\begin{array}{c}\text { Expected to be } \\
\text { small }\end{array}$ & 38,39 & $\mathrm{X}^{2}$ of 86,39 \\
Significance Probability & $\leq 0,05$ & 0,001 & Good \\
RMSEA & $\leq 0,08$ & 0,032 & Good \\
GFI & $\geq 0,90$ & 0,97 & Good \\
AGFI & $\geq 0,90$ & 0,94 & Good \\
NFI & $\geq 0,95$ & 0,96 & Good \\
CFI & $\geq 0,95$ & 0,99 & Good \\
\hline
\end{tabular}

$* * *=\mathrm{x}$.

In addition to using the independent variable $(\mathrm{X})$, this study also used intervening variables. The path analysis method is used to test the effect of the intervening variables. The following is a path analysis to examine the influence of organizational culture and organizational environment on employee performance (Y), then whether the effect of corporate culture and organizational environment on employee performance is mediated by organizational engagement and motivation in Figure 3 below:

Figure 3

Path Analysis Model



The coefficient values are arranged in Table 3 to make it easier to analyze the functional relationship between variables. Based on the second model above, it is possible to interpret each path coefficient. 
Table 3

Performance of Direct Effect Research

\begin{tabular}{lccc}
\hline \multicolumn{1}{c}{ Relationship Structure } & Coefficient & $\begin{array}{c}\text { P } \\
\text { Value }\end{array}$ & Significance \\
\hline Organizational culture $\longrightarrow$ Performance & 0,078 & 0,056 & Sig. \\
Organizational culture $\longrightarrow$ Engagement & 0,414 & 0,001 & Sig. \\
Organizational Environment $\longrightarrow$ Performance & 0,021 & 0,000 & Sig. \\
Organizational Environment $\longrightarrow$ Motivation & 0,231 & 0,001 & Sig. \\
Organizational Engagement $\longrightarrow$ Performance & 0,022 & 0,001 & Sig. \\
Motivation $\longrightarrow$ Performance & 0,234 & 0,001 & Sig. \\
\hline
\end{tabular}

The beta coefficient of organizational culture (X1) on organizational engagement (Y1) is 0.414 at a significance level of 0.001 . The coefficient shows that organizational culture (X1) positively affects organizational engagement (Y1). The beta statistical value of the coefficient of the influence of $\mathrm{X} 1$ on $\mathrm{Y} 1$ is 0.414 with a significance of 0.001 or below 0.05 . That organizational culture (X1) positively and significantly affects organizational engagement (Y1). Thus, hypothesis 1 , which posits that corporate culture and significantly would impact organizational engagement at the Public Works Office in Maluku Province, is accepted.

The coefficient beta of organizational culture (X1) on performance (Y3) is 0.078 at the significance level of 0.056 . The coefficient shows that $\mathrm{X} 1$ has a positive effect on $\mathrm{Y} 3$. The beta statistical value of the influence coefficient of $\mathrm{X} 1$ on $\mathrm{Y} 3$ is 0.078 with a significance of 0.056 or below 0.05 . This means that organizational culture (X1) has a positive and significant effect on employee performance (Y3), so hypothesis 2, which posits that corporate culture would positively and significantly impact employee performance in the Public Works Office in Maluku Province, is accepted.

The coefficient beta of organizational engagement (Y1) on performance (Y3) is 0.022 at a significance level of 0.001 . This coefficient shows that organizational engagement (Y1) positively affects employee performance (Y3). The beta statistical value of the influence coefficient of Y1 on Y3 is 0.022 with a significance of 0.001 or below 0.05 . This means that organizational engagement (Y1) positively and significantly affects employee performance (Y3). Then hypothesis 3, which posits that organizational engagement would have a positive and significant impact on employee performance in the Public Works Office in Maluku Province, is accepted.

The beta coefficient of the influence of the organization environment (X2) on motivation (Y2) is 0.231 at a significance level of 0.001 . The coefficient shows $\mathrm{X} 2$ has a positive effect on $\mathrm{Y} 2$. The beta statistical value of the influence coefficient of X2 on Y2 is 0.231 with a significance of 0.001 or below 0.05 . This means that the organizational environment (X2) positively and significantly affects motivation (Y2). So, hypothesis 4, which posits that environmental organization would have a positive and significant effect on the basis in the Public Works Office in Maluku Province is accepted.

The coefficient beta of the organizational environment (X2) influence employee performance (Y3) is 0.021 at a significance level of 0.000 . The coefficient shows $\mathrm{X} 2$ has a positive effect on Y3. The beta statistical value of the influence coefficient of X2 on Y3 is 0.021 with a significance of 0.000 or below 0.05 . That the organizational environment (X2) has a positive and significant effect on employee performance (Y3), then hypothesis 5, which posits that environmental organization would have a positive and significant impact on employee performance in the Public Works Office in Maluku Province, is accepted. 
The beta coefficient of the influence of motivation (Y2) on performance (Y3) is 0.234 at a significance level of 0.001 . The coefficient shows that $\mathrm{Y} 2$ has a positive effect on Y3. The beta statistical value of the influence coefficient of Y2 on Y3 is 0.234 with a significance of 0.001 or below 0.05 . This means that motivation (Y2) has a positive and significant effect on employee performance (Y3), so hypothesis 6 , which posits that motivation would have a positive and significant impact on employee performance in the Public Works Office in Maluku Province, is accepted.

Figure 4 presents the structural model. Testing was carried out to determine the significance of the indirect effect; if the T-model value is greater than the value of 1.96, it can be concluded that there is a mediating effect.

\section{Figure 4}

\section{T-Model of Interest}

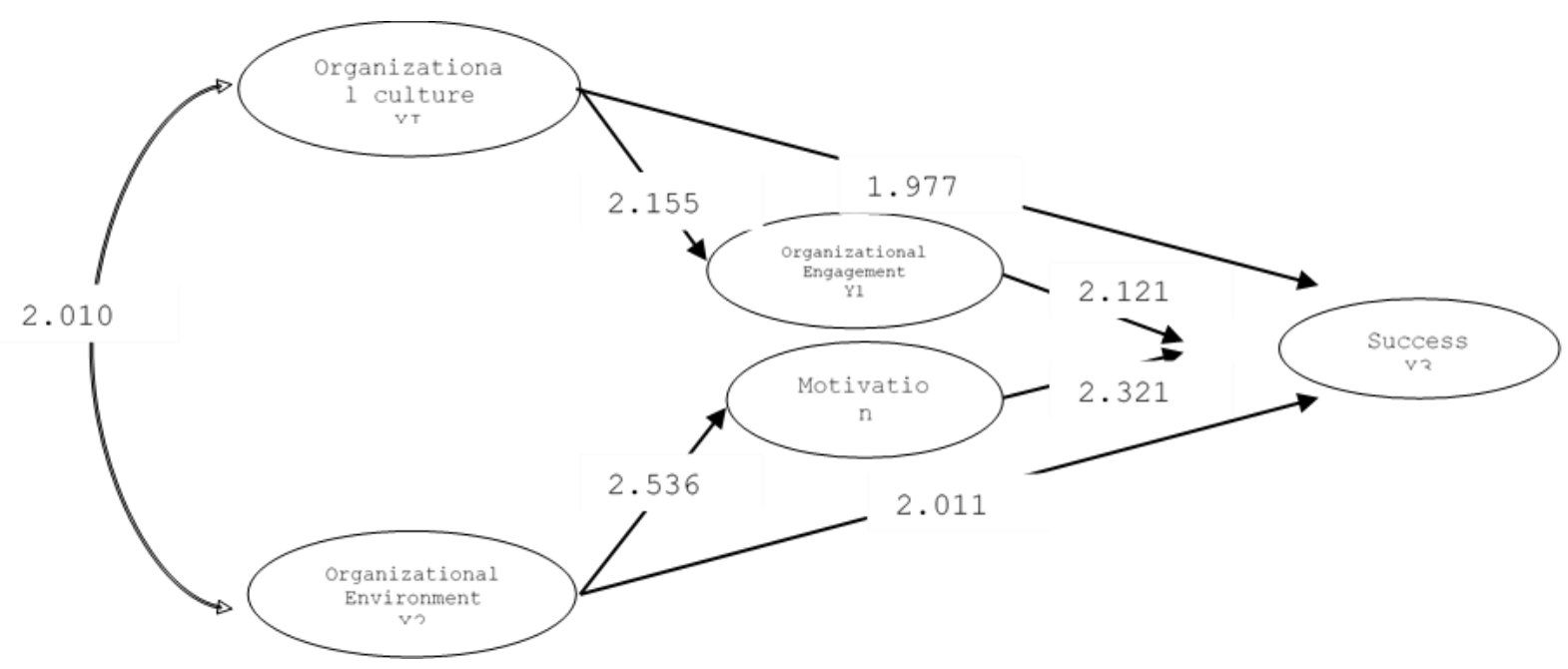

The direct effect is an independent variable's influence on an accepted variable or a direction model defined by a single arrow. The indirect path is through the intermediate variable or the intermediate variable. Intervening variables are referred to as control variables, which may shift direction, and a coefficient how's the degree of importance of an ability or a compilation relationship or one or more variables used in a model. Table 4 shows the indirect effect between the variables examined based on the causal relationship and the structural model.

\section{Table 4}

Indirect Effect Analysis Results

\begin{tabular}{llc}
\hline Number & Indirect Effect & Value \\
\hline 1 & The indirect influence of X1 on Y3 by Y1 & 0,211 \\
2 & The indirect influence of X2 on Y3 by Y2 & 0,728 \\
\hline$* * *=\mathrm{x}$. & &
\end{tabular}

Based on Table 4, the T model value of the indirect influence of organizational culture (X1) on employee performance (Y3) through organizational engagement (Y1) is 0.211 with T model 1.977> 1.96. Thus, hypothesis 2 , which posits that organizational culture would positively and significantly affect employee performance through organizational engagement at the Public Works Office in Maluku Province, is accepted. The value of the T model, the indirect effect of the 
organizational environment (X2) on employee performance (Y3) through motivation (Y2), is 0.728 with the T model 2.011> 1.96. Thus, hypothesis 5, which posits that environmental organization would positively and significantly affect employee performance through motivation at the Public Works Office in Maluku Province, is accepted.

\section{Discussion and Conclusion}

\section{The Influence of Organizational Culture on Organizational Engagement}

This research shows a positive and significant effect of organizational culture on corporate engagement, which is seen from the direct influence path analysis results. The results of this study are in line with Harwiki (2016) that every culture is said to be effective in the organization if the employees have good organizational engagement. According to Mitic et al. (2016), engagement can be successful if the culture is wise, exemplary, disciplined, and applies all procedures consequently and avoids favoritism that can lead to prejudice, resentment, and social jealousy.

Employee performance will improve if the corporate culture and organizational engagement is appropriately implemented (Silverthorne, 2004). Every work done requires standards and the ability to measure oneself or subordinates' performance, compare performance with standards under existing provisions, and continuously evaluate the activities' results to determine the need for corrective action in future activities. Employee loyalty to the company is a behavioral factor that can be used to determine and evaluate employees' ability to survive and carry out their duties and responsibilities to the organization (Arumi et al., 2019). Commitment is perceived as a value orientation toward the organization, demonstrating that individuals seriously consider and prioritize their work and the organization. Individuals will continue to give their all to help the company accomplish its goals (Acar, 2012).

The managerial implication of the influence of organizational culture on organizational engagement is the attitude of employees who are obedient to the norms and regulations set by the workplace by increasing togetherness utilizing analysis, namely a culture that can determine and analyze steps for achieving goals (Goula et al., 2021; Zeb et al., 2021). Then, a dynamic culture will be able to adapt to achieve goals in a programmed, structured, and conceptual manner. Furthermore, in the implementation of decision-making in organizations, innovation and opportunities are related to policy (Namli, 2021; Sapta et al., 2021).

\section{The Influence of Organizational Culture on Employee Performance}

The influence of organizational culture variables on employee performance was positive. An improvement will follow an increase in corporate culture in employee performance if other factors that affect organizational culture are considered constant. This research shows a positive and significant influence of corporate culture on employee performance. The results of this study are in line with Ogbonna and Harris (2000), explaining that employee performance is the result of performance that can be achieved by a person or group of people in an organization, following their respective authorities, duties, and responsibilities to achieve goals. An organization concerned legally does not violate the law and has appropriate morals and ethics. Özçelik and Ferman (2006) argued that employee performance is an attitude of discipline; employee discipline is vital for the smooth running of a company.

The managerial implication of the influence of organizational culture on employee performance is the attitude of employees who are obedient to the norms and regulations that the workplace has established (Giberson et al., 2009; Hamid \& Durmaz, 2021). By improving the 
organizational culture via a benefits orientation, management focuses on results or benefits rather than just techniques. Moreover, the process can be used to obtain these benefits and then expose people to office management decisions and consider the effect of services on people in an organization. Furthermore, team orientation is organized based on teams and stability and not individually (Kantabutra, 2021).

\section{The Influence of Organizational Engagement on Employee Performance}

The influence of the organizational engagement variable on employee performance was positive. An increase in organizational engagement will be followed by improvements in employee performance, assuming other factors that affect organizational engagement remain constant. This research shows a positive and significant influence of organizational engagement on employee performance. The results of this study are in line with Bunch (2007). Solid engagement can significantly affect individuals and performance; even in a competitive environment, this influence is better than other factors such as organizational structure, financial analysis tools, leadership, and others. Organizational engagement that is easy to adapt to changing times (adaptive) is what can improve performance.

The managerial implication of the influence of organizational engagement on employee performance indicates that a well-implemented engagement will improve employee performance in the Public Works Office in Maluku Province. The results of this study align with Gambi et al. (2015) in that a working system with engagement positively impacts employee performance. To improve the application of a work engagement system that has a motivational impact on employee performance, the Public Works Office of Maluku Province must pay attention to the clarity of work agreements, years of service, and employee wages. For example, if an employee understands the work that is his responsibility and the company hire employees according to the agreement contained in a work engagement, this will encourage employees to work per the provisions set by the office (Ipinazar et al., 2021; Sawan, 2021). Thus, employee performance will increase andimprove office performance (Sugiono et al., 2021).

\section{The Influence of Organizational Environment on Motivation}

The influence of organizational environmental variables on motivation was positive. This means that an improvement will follow an increase in motivation in the organizational environment if other factors that affect the organizational environment are considered constant. This research shows the positive and significant influence of the organizational environment on motivation. This indicates that the organizational environment is a force that encourages employee morale, which includes rewards and punishment.

This consists of a physical work environment and a non-physical work environment. Employees are motivated to complete work because their needs to exist, establish relationships, and develop are met (Sugiartha et al., 2021). This study supports the opinion of Buch and Wetzel (2001), which states that factors creating work motivation include excellent working conditions, especially in terms of the physical work environment. The feeling is included in all administrative and management processes and applies to all levels and positions (Koc et al., 2021). Work motivation is also influenced by a humane way of disciplining that every member of the organization is an ordinary human being who is not free from weaknesses, deficiencies, and even mistakes (Maswadeh \& Zumot, 2021). An attitude should be considered objectively, and the punishment given should be proportional to the mistakes made (Silverthorne, 2004). Motivation is 
also related to awarding rewards for carrying out tasks well (Asree et al., 2010).

\section{The Influence of Organizational Environment on Employee Performance}

The influence of organizational environmental variables on employee performance was positive. An improvement in employee performance will follow an increase in the organizational environment if other factors that affect the organizational environment remain constant. This research shows the positive and significant influence of the organizational environment on employee performance. If lighting, air circulation, noise, safety in the workplace, employee relations at the Public Works Office of Maluku Province have been fulfilled, employee performance will improve. Jung et al. (2009) stated that a safe and comfortable work environment is proven to affect employee productivity. The more the Public Works Office of Maluku Province pays attention to the work environment factors of employees, the more employees will show an increase in performance in serving clients. Based on the respondents' responses, the impact of the work environment is high. The highest work environment indicator felt by the staff of the Public Works Office of Maluku Province indicates that the Public Works Office has good information and supports the provision of services.

Feeling comfortable and happy will influence employees to be more active, diligent, and eager to work, and if the work environment is terrible, this will result in decreased employee performance. Thus, the organization should always strive for more adequate facilities and infrastructure to make working comfortable. An organization that does so is likely to create a harmonious relationship with employees so that they think that they are treated fairly in the work environment (Top et al., 2013). A bad work environment will adversely affect workers because they feel disturbed in their work, so that they cannot pay attention to their work, resulting in decreased employee performance (Gambi et al., 2015).

\section{The Influence of Motivation on Employee Performance}

The influence of motivation variables on employee performance was positive. Improvements will follow increased motivation in employee performance if other factors that influence motivation are considered constant. This study shows a positive and significant influence of motivation on employee performance. The results of this study support the research of Silverthorne (2004) that work motivation has a significant effect on employee performance. Work motivation is essential in increasing work effectiveness. Because people who have high work motivation will try their best to be successful, if their personal needs are met, they can work harder and be more enthusiastic (Asree et al., 2010).

Some high work motivation is required to improve employee performance. Therefore, work motivation has a very close relationship with employee performance. With individual work motivation, employees will work optimally in a company (Ridlwan et al., 2021). Work motivation is formed from the attitude of employees facing working conditions. Work motivation is a condition that encourages employees to be focused on achieving their goals (Dwivedi et al., 2014). An organizational environment should provide appropriate work motivation by looking at the behavior shown by employees and choosing ways that it can use to motivate employees to work (Imron et al., 2021). 


\section{Conclusion}

The results showed that the variables of organizational culture and organizational environment had a direct and indirect influence on increasing organizational engagement, motivation, and employee performance. These variables need to be maintained significantly to improve employee performance. The organizational environment and organizational culture can be a reference for the Public Works Office of Maluku Province in making policies related to improving employee performance.

Every organization must have a culture. Organizational culture and environment are significant for the company's long-term survival. Company culture is a foundation that contains norms, beliefs, how workers work, and behaviors that contribute to the quality of the organization's success. Due to the diversity of highly respected cultures, the deep local wisdom of Indonesia, with different cultures and religions, can flourish. The most successful way to respond to changing times is to create a culture and organizational environment that reflects Indonesia's superior diversity. The government will have sufficient resources to succeed as a developing country in globalization if it has a distinctive and acceptable organizational culture.

It is, of course, impossible to make general conclusions when applied to other factors outside the objectives of this research. Future research is recommended to add additional independent variables besides organizational culture, organizational environment, organizational engagement, and motivation, which can affect the dependent variable of employee performance.

\section{References}

Acar, A. Z. (2012). Organizational culture, leadership styles and organizational commitment in Turkish logistics industry. Procedia - Social and Behavioral Sciences, 58, 217-226. https://doi.org/10.1016/j.sbspro.2012.09.995

Aktaş, E., Çiçek, I., \& Kiyak, M. (2011). The effect of organizational culture on organizational efficiency: The moderating role of organizational environment and CEO values. Procedia - Social and Behavioral Sciences, 24, 1560-1573. https://doi.org/10.1016/j.sbspro.2011.09.092

Alavi, M., Kayworth, T. R., \& Leidner, D. E. (2005). An empirical examination of the influence of organizational culture on knowledge management practices. Journal of Management Information Systems, 22(3), 191-224. https://doi.org/10.2753/MIS0742-1222220307

Albrecht, S., Breidahl, E., \& Marty, A. (2018). Organizational resources, organizational engagement climate, and employee engagement. Career Development International.

Arumi, M. S., Aldrin, N., \& Murti, T. R. (2019). Effect of organizational culture on organizational citizenship behavior with organizational commitment as a mediator. International Journal of Research in Business and Social Science, 8(4), 124-132. https://doi.org/10.20525/ijrbs.v8i4.274

Asree, S., Zain, M., \& Razalli, M. R. (2010). Influence of leadership competency and organizational culture on responsiveness and performance of firms. International Journal

of Contemporary Hospitality Management, 22(4), 500-516. https://doi.org/10.1108/09596111011042712

Baumgartner, R. J. (2009). Organizational culture and leadership: Preconditions for the development of a sustainable corporation. Sustainable Development, 17(2), 102-113. https://doi.org/10.1002/sd.405

Becker, B. E., \& Huselid, M. A. (2006). Strategic human resources management: Where do we go 
from here. Journal of Management, 32(6), 898-925. https://doi.org/10.1177/0149206306293668

Boiral, O., \& Paillé, P. (2012). Organizational citizenship behavior for the environment: Measurement and validation. Journal of Business Ethics, 109(4), 431-445. https://doi.org/10.1007/s10551-011-1138-9

Boyd, B. (1990). Corporate linkages and organizational environment: A test of the resource dependence model. Strategic Management Journal, 11(6), 419-430. https://doi.org/10.1002/smj.4250110602

Buch, K., \& Wetzel, D. K. (2001). Analyzing and realigning organizational culture. Leadership \& Organization Development Journal, 40-44. https://doi.org/10.1108/01437730110380219

Budiharso, T., \& Tarman, B. (2020). Improving quality education through better working conditions of academic institutes. Journal of Ethnic \& Cultural Studies, 7(1), 99-115. http://www.ejecs.org/index.php/JECS/article/view/306

Bunch, K. J. (2007). Training failure as a consequence of organizational culture. Human Resource Development Review, 6(2), 142-163. https://doi.org/10.1177/1534484307299273

Chatman, J. A., \& O'Reilly, C. A. (2016). Paradigm lost: Reinvigorating the study of organizational culture. In Research in Organizational Behavior (Vol. 36, pp. 199-224). JAI Press. https://doi.org/10.1016/j.riob.2016.11.004

Dwivedi, S., Kaushik, S., \& Luxmi. (2014). Impact of organizational culture on commitment of employees: An empirical study of BPO sector in India. Vikalpa.: The Journal for Decision Makers, 39(3), 77-92. https://doi.org/10.1177/0256090920140306

Eby, L. T., \& Rothrauff-Laschober, T. C. (2012). The relationship between perceptions of organizational functioning and voluntary counselor turnover: A four-wave longitudinal study. Journal of Substance Abuse Treatment, 42(2), 151-158. https://doi.org/10.1016/j.jsat.2011.10.008

Gambi, L. D. N., Boer, H., Gerolamo, M. C., Jørgensen, F., \& Carpinetti, L. C. R. (2015). The relationship between organizational culture and quality techniques, and its impact on operational performance. International Journal of Operations \& Production Management, 35(10), 1460-1484. https://doi.org/10.1108/IJOPM-12-2013-0563

Giberson, T. R., Resick, C. J., Dickson, M. W., Mitchelson, J. K., Randall, K. R., \& Clark, M. A. (2009). Leadership and organizational culture: Linking CEO characteristics to cultural values. Journal of Business \& Psychology, 24(2), 123-137. https://doi.org/10.1007/s10869009-9109-1

Goula, A., Stamouli, M. -A., Latsou, D., Gkioka, V., \& Kyriakidou, N. (2021). Learning organizational culture in Greek public hospitals. International Journal of Environmental Research \& Public Health, 18(4), 1867. https://doi.org/10.3390/ijerph18041867

Hameed, A., \& Waheed, A. (2011). Employee development and its affect on employee performance a conceptual framework. International Journal of Business \& Social Science, 2(13).

Hamid, D., \& Durmaz, O. (2021). Organizational culture impact on employee innovative behaviors in Kurdistan. Black Sea Journal of Management \& Marketing, 2(1), 63-72. https://doi.org/10.47299/bsjmm.v2i1.68

Harwiki, W. (2016). The impact of servant leadership on organization culture, organizational commitment, organizational citizenship behaviour (OCB) and employee performance in women cooperatives. Procedia - Social \& Behavioral Sciences, 219, 283-290. https://doi.org/10.1016/j.sbspro.2016.04.032

Imron, M. A., Munawaroh, U. I., Farida, R. D. M., Paramarta, V., Sunarsi, D., Akbar, I. R., Effendy, 
A. A., Siagian, A. O., \& Masriah, I. (2021). Effect of organizational culture on innovation capability employees in the knowledge sharing perspective: Evidence from digital industries. Annals of the Romanian Society for Cell Biology, 4189-4203. http://annalsofrscb.ro/index.php/journal/article/view/1437

Ipinazar, A., Zarrabeitia, E., Belver, R. M. R., \& de Alegría, I. M. (2021). Organizational culture transformation model: Towards a high performance organization. Journal of Industrial $\begin{array}{llll}\text { Engineering } \quad \text { M } & \text { 14(1), 25-44. }\end{array}$ http://www.jiem.org/index.php/jiem/article/view/3288/950

Isaac, S., \& Michael, W. B. (1995). What sample size is 'enough' in Internet survey research? In Handbook in research and evaluation ( $3^{\text {rd }}$ ed.). Edits.

Jung, T., Scott, T., Davies, H. T. O., Bower, P., Whalley, D., McNally, R., \& Mannion, R. (2009). Instruments for exploring organizational culture: A review of the literature. Public Administration Review, 69(6), 1087-1096. https://doi.org/10.1111/j.15406210.2009.02066.x

Kantabutra, S. (2021). Exploring relationships among sustainability organizational culture components at a leading asian industrial conglomerate. Sustainability, 13(4), 1733.

Karakuş, M. (2018). The moderating effect of gender on the relationships between age, ethical leadership, and organizational commitment. Journal of Ethnic \& Cultural Studies, 5(1), 7484.

Koc, Y., Gulseren, D., \& Lyubykh, Z. (2021). Masculinity contest culture reduces organizational citizenship behaviors through decreased organizational identification. Journal of Experimental Psychology: Applied. Advanced online publication. https://doi.org/10.1037/xap0000351

Kuenzi, M., Mayer, D. M., \& Greenbaum, R. L. (2020). Creating an ethical organizational environment: The relationship between ethical leadership, ethical organizational climate, and unethical behavior. Personnel Psychology, 73(1), 43-71. https://doi.org/10.1111/peps.12356

Lam, L., Nguyen, P., Le, N., \& Tran, K. (2021). The relation among organizational culture, knowledge management, and innovation capability: Its implication for open innovation. Journal of Open Innovation: Technology, Market, \& Complexity, 7(1), 66. https://doi.org/10.3390/joitmc7010066

Lindner, J. R. (1998). Understanding employee motivation. Journal of Extension, 36(3), 1-8.

Linnenluecke, M. K., \& Griffiths, A. (2010). Corporate sustainability and organizational culture. Journal of World Business, 45(4), 357-366. https://doi.org/10.1016/j.jwb.2009.08.006

Lockrey, S. (2015). A review of life cycle based ecological marketing strategy for new product development in the organizational environment. In Journal of Cleaner Production (Vol. 95, pp. 1-15). Elsevier Ltd. https://doi.org/10.1016/j.jclepro.2015.02.022

Luo, Y. (2005). An organizational perspective of corruption. Management and Organization Review, 1(1), 119-154. https://doi.org/10.1111/j.1740-8784.2004.00006.x

Machado, D. D. P. N., \& Carvalho, C. E. (2008). Cultural typologies and organizational environment: A conceptual analysis. Latin American Business Review, 9(1), 1-32.

Mahrous, A., Genedy, M. A., \& Kalliny, M. (2020). The impact of characteristics of intraorganizational environment on entrepreneurial marketing intensity and performance in Egypt. Journal of Entrepreneurship in Emerging Economies, 12(5), 621-642. https://doi.org/10.1108/JEEE-08-2019-0115

Manoharan, A. P., Ingrams, A., Kang, D., \& Zhao, H. (2021). Globalization and worldwide best practices in E-Government. International Journal of Public Administration, 44(6), 465- 
476.

Martinez, E. A., Beaulieu, N., Gibbons, R., Pronovost, P., \& Wang, T. (2015). Organizational culture and performance. American Economic Review, 105(5), 331-335. https://doi.org/10.1257/aer.p20151001

Maswadeh, S., \& Zumot, R. (2021). The effect of total quality management on the financial performance by moderating organizational culture. Accounting, 7(2), 441-450. https://doi.org/10.5267/j.ac.2020.11.007

Miller, L. (2018). Social networking strategy for creating public value in Eastern India. Journal of Ethnic and Cultural Studies, 5(1), 85-93.

Mitic, S., Vukonjanski, J., Terek, E., Gligorovic, B., \& Zoric, K. (2016). Organizational culture and organizational commitment: Serbian case. Journal of Engineering Management \& Competitiveness, 6(1), 21-27. https://doi.org/10.5937/jemc1601021m

Mustafa, D., Farida, U., \& Yusriadi, Y. (2020). The effectiveness of public services through Egovernment in Makassar City. International Journal of Scientific \& Technology Research, 9(1), 1176-1178.

Namli, U. (2021). Behavioral Changes among Street Level Drug Trafficking Organizations and the Fluctuation in Drug Prices Before and During the Covid-19 Pandemic. American Journal of Qualitative Research, 5(1), 1-22. https://doi.org/10.29333/ajqr/9691

Naranjo-Valencia, J. C., Jiménez-Jiménez, D., \& Sanz-Valle, R. (2011). Innovation or imitation? The role of organizational culture. Management Decision, 49(1), 55-72. https://doi.org/10.1108/00251741111094437

Ogbonna, E., \& Harris, L. C. (2000). Leadership style, organizational culture and performance: Empirical evidence from UK companies. International Journal of Human Resource Management, 11(4), 766-788. https://doi.org/10.1080/09585190050075114

Ostroff, C., Kinicki, A. J., \& Muhammad, R. S. (2012). Organizational culture and climate. In Handbook of psychology (2nd ed.). John Wiley \& Sons, Inc. https://doi.org/10.1002/9781118133880.hop212024

Özçelik, G., \& Ferman, M. (2006). Competency approach to human resources management: Outcomes and contributions in a Turkish cultural context. Human Resource Development Review, 5(1), 72-91. https://doi.org/10.1177/1534484305284602

Paais, M., \& Pattiruhu, J. R. (2020). Effect of motivation, leadership, and organizational culture on satisfaction and employee performance. The Journal of Asian Finance, Economics, \& Business, 7(8), 577-588. https://doi.org/10.13106/JAFEB.2020.VOL7.NO8.577

Prajogo, D. I., \& McDermott, C. M. (2011). The relationship between multidimensional organizational culture and performance. International Journal of Operations \& Production Management, 31(7), 712-735. https://doi.org/10.1108/01443571111144823

Ridlwan, M., Purwandari, D. A., \& Syah, T. Y. R. (2021). The effect of situational leadership and organizational culture on employee performance through job satisfaction. International Journal of Multicultural \& Multireligious Understanding, 8(3), 73-87. https://ijmmu.com/index.php/ijmmu/article/view/2378/2063

Sapta, I., Muafi, M., \& Setini, N. M. (2021). The role of technology, organizational culture, and job satisfaction in improving employee performance during the Covid-19 pandemic. The Journal of Asian Finance, Economics, and Business, 8(1), 495-505.

Sawan, F. (2021). Impact of organizational culture on knowledge sharing behavior. In Proceedings of the 4th International Conference on Research of Educational Administration and Management (ICREAM 2020) (pp. 331-335). https://doi.org/10.2991/assehr.k.210212.073

Schein, E. H. (1990). Organizational culture. (Vol. 45, Issue 2). American Psychological Association. 
Silverthorne, C. (2004). The impact of organizational culture and person-organization fit on organizational commitment and job satisfaction in Taiwan. Leadership \& Organization Development Journal, 25(7), 592-599. https://doi.org/10.1108/01437730410561477

Singh, P. J., Power, D., \& Chuong, S. C. (2011). A resource dependence theory perspective of ISO 9000 in managing organizational environment. Journal of Operations Management, 29(12), 49-64. https://doi.org/10.1016/j.jom.2010.04.002

Sugiartha, K. A., Yuesti, A., \& Sudja, I. N. (2021). Leadership and organizational culture in the department of transportation Badung Regency. Journal of Contemporary Issues in Business and Government, 27(1), 1856-1870. https://cibg.org.au/pdf_8422_edbb2a91a2c31b62bc9404f7eeff9833.html

Sugiono, E., Efendi, S., \& Afrina, Y. (2021). The effect of training, competence and compensation on the performance of new civil servants with organizational culture as intervening: competence at the Ministry of Health of the Republic of Indonesia. International Journal of Science \& Society, 3(1), 262-279. https://doi.org/10.200609/ijsoc.v3i1.292

Svetlik, I., \& Stavrou-Costea, E. (2007). Connecting human resources management and knowledge management. In International Journal of Manpower (Vol. 28, Issues 3-4, pp. 197-206). Emerald Group Publishing Limited. https://doi.org/10.1108/01437720710755209

Tamsah, H., Ansar, Ilyas, G. B., Yusriadi, Y., \& Farida, U. (2020). Training, knowledge sharing, and quality of work-life on civil servants' performance in Indonesia. Journal of Ethnic \& Cultural Studies, 7(3), 163-176. https://doi.org/10.29333/ejecs/514

Tarman, B. (2018). The awareness of social studies teacher candidates' regarding special area competencies and the overlap level of these competencies with social studies degree. Journal of Ethnic and Cultural Studies, 5(2), 16-28.

Top, M., Tarcan, M., Tekingündüz, S., \& Hikmet, N. (2013). An analysis of relationships among transformational leadership, job satisfaction, organizational commitment and organizational trust in two Turkish hospitals. The International Journal of Health Planning \& Management, 28(3), e217-e241. https://doi.org/10.1002/hpm.2154

Tracey, J. B. (2014). A review of human resources management research: The past 10 years and implications for moving forward. International Journal of Contemporary Hospitality Management, 26(5), 679-705. https://doi.org/10.1108/IJCHM-02-2014-0056

Umar, A., Amrin, Madani, M., Farida, U., Yusriadi, Y., Tamsa, H., Bahtiar, Ansar, Yahya, M., Nurnaningsih, Alam, S., Gunawan, H., Darwis, Sahabuddin, C., Jamaluddin, Misbahuddin, Elpisah, Akbar, Z., Sakkir, G., ... Misnawati, M. (2019). One-stop service policy as a bureaucratic reform in Indonesia. Academy of Strategic Management Journal, 18(2), 1-12. https://search.proquest.com/openview/ba922d5b89db0ba315ec4df51bfca746/1?pqorigsite $=$ gscholar $\& \mathrm{cbl}=38745$

Vardarlier, P. (2016). Strategic approach to human resources management during crisis. Procedia - Social and Behavioral Sciences, 235, 463-472. https://doi.org/10.1016/j.sbspro.2016.11.057

Wang, M. S., \& Lounsbury, M. (2021). Cultural encounters: A practice-driven institutional approach to the study of organizational culture. In M. Lounsbury, D. A. Anderson, \& P. Spee (Eds.), On practice and institution: New empirical directions. Research in the sociology of organizations (Vol. 71, pp. 165-198). Emerald Publishing Limited.

Yusriadi, Sahid, A., Amirullah, I., Azis, A., \& Rahman, A. A. (2019). Bureaucratic reform to the human resources: A case study on the one-stop integrated service. Journal of Social Sciences Research, 5(1), 61-66. https://doi.org/10.32861/jssr.51.61.66 
Závadská, Z., \& Závadský, J. (2020). Quality managers and their future technological expectations related to Industry 4.0. Total Quality Management \& Business Excellence, 31(7-8), 717741. https://doi.org/10.1080/14783363.2018.1444474

Zeb, A., Akbar, F., Hussain, K., Safi, A., Rabnawaz, M., \& Zeb, F. (2021). The competing value framework model of organizational culture, innovation and performance. Business Process Management Journal.

\section{Notes on Contributors}

Tehubijuluw Zacharias is a lecturer in Social Science at the Social Welfare Science Department of Universitas Kristen Indonesia Maluku. His work focuses on teaching, learning, research, and community services. He works and teaches primarily social sciences. His areas of interest and research include social sciences, political science, sociology, legal studies, and public administration. He has published books and many articles in national and international journals.

Mohamad Arsad Rahawarin is a lecturer in Public Administration at Public Administration Graduate Program of Universitas Pattimura, Maluku, Indonesia. He is also chair of the Postgraduate Public Administration study program at Universitas Pattimura, Maluku. His work focuses on teaching, learning, research, and community services. He works and teaches primarily public administration. His areas of interest and research include social sciences, political science, sociology, legal studies, and public administration. He has published books and many articles in national and international journals.

Yusriadi Yusriadi is a lecturer in Public Administration at Public Administration Graduate Program of Sekolah Tinggi Ilmu Administrasi Puangrimaggalatung, Makassar, Indonesia. He is also the chancellor at Sekolah Tinggi Ilmu Hukum Pengayoman, Makassar, Indonesia. His work focuses on teaching, learning, research, and community services. He works and teaches primarily public administration. His areas of interest and research include social sciences, political science, sociology, legal studies, and public administration. He is a reviewer and editor of local and international journals. https://orcid.org/0000-0001-7908-1525 